UDC 369

\title{
POVERTY ALLEVIATION INNOVATION THROUGH GERTAK (GERAKAN TENGOK BAWAH MASALAH KEMISKINAN) PROGRAM IN TRENGGALEK REGENCY
}

\author{
Rahmawati Dyah Ayu*, Saleh Choirul, Rozikin Moch. \\ Magister Program in Public Administration, Faculty of Administrative Science, \\ University of Brawijaya, Indonesia \\ *E-mail: ayurahmady18@gmail.com
}

\begin{abstract}
Poverty is an old problem that is commonly encountered in almost all developing countries, especially in densely populated countries such as Indonesia. Poverty should be a common problem that needs to be addressed seriously because poverty is neither a private nor a specific group issue (government), but it is a matter of every Indonesian citizen. Awareness among fellow citizens is expected to help reducing the poverty level in Indonesia. To this day, National and Local Government in Indonesia have faced multidimensional poverty problem. Moreover, the implemented poverty reduction programs are often incompatible with the conditions of each region. Of course, it causes its implementation to be vulnerable to various forms of abuse or misappropriation. By looking at the conditions of different regions, the local government of Trenggalek Regency issued a poverty reduction program that is adapted to the current condition of Trenggalek Regency. This program is a government innovation for poverty alleviation in Trenggalek Regency. Gertak Program in Trenggalek Regency is a new program that promotes the welfare and prosperity of the poor which aim to eradicate poverty in Trenggalek Regency.
\end{abstract}

\section{KEY WORDS}

Innovation, poverty reduction, Gertak program, policies.

Poverty is a major problem in our country where the poor condition occurs in various areas and is characterized by vulnerability, helplessness, isolation and inability to convey aspirations. In addition, Tontowi (2010) describes that the poor conditions can result in: burdensome condition (socio-economically) on society, low quality and productivity of society, low level of active participation of society, declining level of public order and public peace, decreasing level of public trust in bureaucracy in giving service to society, possibility of lost of generations.

The impact of the economic crisis is felt by the citizen, especially people who live in urban and rural areas. The large number of urban people who lost their jobs is one of the real effects of the existence of the economic crisis. The condition is illustrated by the high number of poor people and open unemployment, as well as the low Human Development Index in Indonesia compared to the majority of other countries. Rather than succeeding in boosting economic growth, eradicating poverty and rising from a downturn, the reality of the field show how business uncertainty, slowing economic growth, and a decline in people's purchasing power continue to color the lives of ordinary people.

Overall poverty reduction programs are often incompatible with the conditions of each region. Of course it causes its implementation to be vulnerable to various forms of abuse or misappropriation. By looking at the conditions of different regions, the local government of Trenggalek Regency issued a poverty reduction program that is adapted to the current condition of Trenggalek Regency. This program is a government innovation for poverty alleviation in Trenggalek Regency.

Currently, Trenggalek Regency is implementing an innovative GERTAK (Gerakan Tengok Bawah Masalah Kemiskinan) program to eradicate poverty. This Gertak program is a new innovation program implemented by the government of Trenggalek Regency in 2017. GERTAK Program has been launched by Trenggalek Regency since May 12, 2016. GERTAK program is one form of implementation in realizing the vision and mission of 
Trenggalek Regent, Dr. Emil Elestianto Dardak, M.Sc, and Vice Regent, H. Moch. Nur Arifin, that is to realize Trenggalek that is developed, fair, prosperous, and has a good personality that is based on faith and taqwa.

\section{METHODS OF RESEARCH}

In this study, the researchers used descriptive research with a qualitative approach. Qualitative research is a study that intends to understand the phenomenon of what is experienced by research subjects, such as behavior, perception, motivation, action, etc., holistically, in descriptive way in the form of words and language, in a special scientific context and by utilizing various scientific methods (Moleong, 2010: 6). The focuses of this research were; 1) poverty reduction innovation through Gertak Program in Trenggalek Regency includes: a. Innovation typology of Gertak Program, b. Continuity and sustainability of Gertak Program innovation in Trenggalek Regency: institutional, budget support, human resources, SOP (Standard Operating Procedure); 2) The relevance of poverty reduction innovation to poverty reduction through Gertak Program in Trenggalek Regency.

In this research, the selected location was in Trenggalek Regency, East Java Province. This area was an area with high poverty rate in East Java. On the other hand, the research site was a place where the researchers should be able to capture the true state of the object under study. The research site for this study consisted of; 1. BAPPEDA (Development Planning Agency at Sub-Nasional Level) of Trenggalek Regency, and 2. GERTAK Post of Trenggalek Regency. The type of research used by qualitative research was often called as naturalistic research method because the research was done on natural condition. It was also called as ethnography method. Data sources in this qualitative research were human, event, research location and document (photos, files, archives, journals and reports). The research instruments for this research were the researchers themselves, interviews and supporting tools (recorder and camera). The researchers used Creswell data analysis in analyzing the obtained data because it could easily translate all of the existing data into an information, and it was also considered as a new theory. Creswell (2012: 27) provided an understanding that the ideal way was to mix these general procedures with special steps.

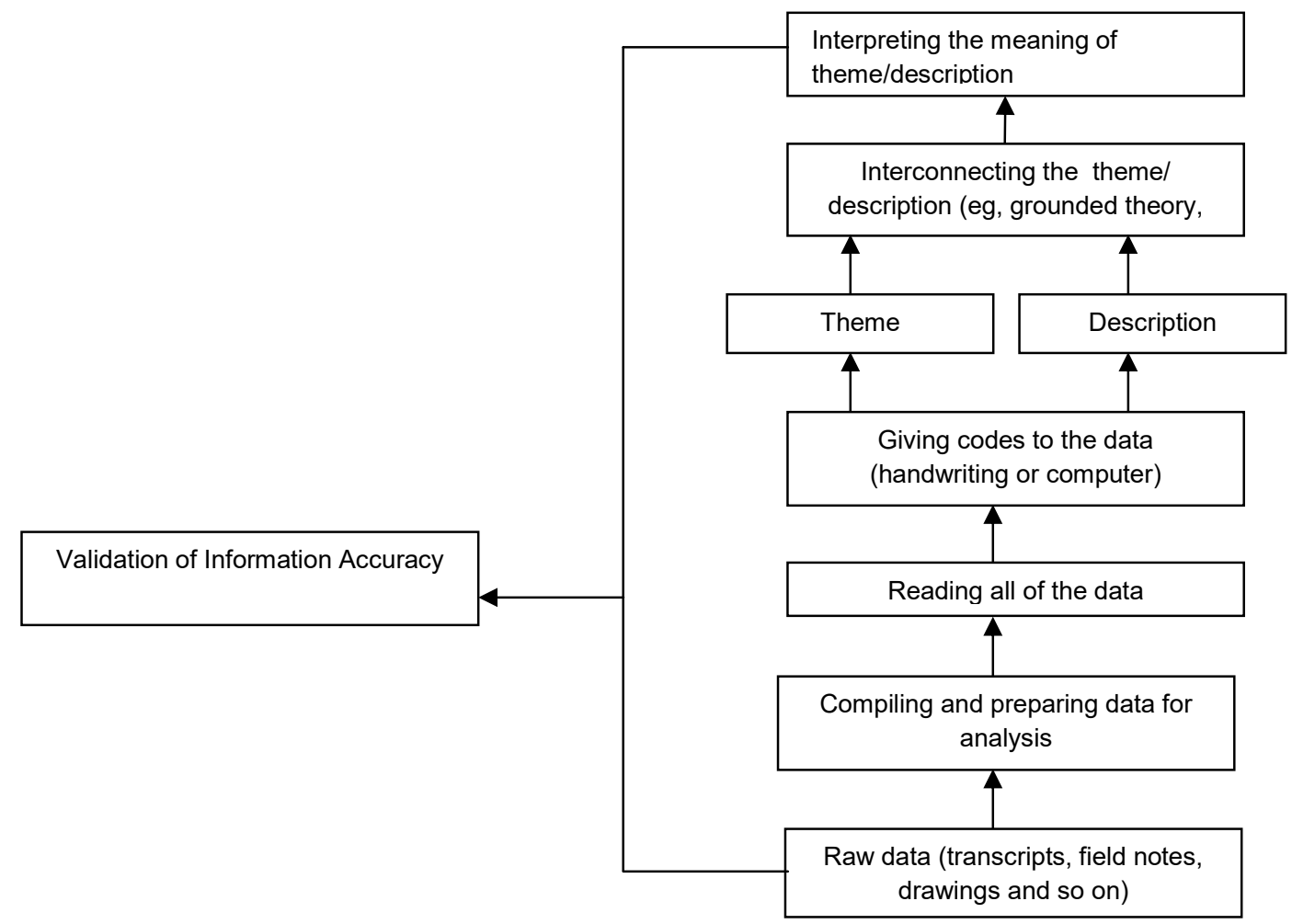

Figure 1 - Qualitative Research Data Analysis by Creswell (Source: Creswell, 2016: 263) 


\section{RESULTS AND DISCUSSION}

Poverty Reduction Innovation through Gertak Program in Trenggalek Regency. Efforts to innovate the public sector in poverty alleviation in the region continued to be done by the Regional Government and it was supported by Presidential Decree No. 7/2014 on the Implementation of Prosperous Family Deposit Program, Smart Indonesia Program, and Healthy Indonesia Program to build productive families. The concept of innovative poverty reduction planning that has been in accordance with research from Widodo (2015), that the concept of innovative programs of UPTPK (Unit Pelayanan Terpadu Penanggulangan Kemiskinan/Integrated Service Unit on Poverty Alleviation) were broadly divided into four, namely: programs in the field of health, education, socio-economy, and UPTPK in Subdistrict. UPTPK was expected to be a friendly, prime and procedural servant of the poor. It could also facilitate services for the poor to meet health, education and socio-economic needs. Besides, there was another regulation, namely the Regulation of the Minister of Home Affairs Number 42 of 2010 on the Coordination Team for Provincial and Regency/City Poverty Reduction. In legislation, there was a mandate that must be implemented by the Regional Poverty Reduction Coordination Team (TKPKD), both Province and Regency/City, that was preparing Regional Poverty Reduction Strategy (SPKD). Trenggalek Regency government issued Regent Regulation No. 14 of 2015 on General Guidelines of Anti-Poverty Program of Trenggalek Regency in 2015.

Innovation Typology of Gertak Program. In an effort to reduce the poverty rate in Trenggalek Regency, the changes/innovations offered were strengthening the role of TKPKD and developing an integrated poverty reduction management system through Self Defined Poverty System (SDPS). In principle, this SDPS was a system developed in the implementation of the GERTAK Program innovation strategy through:

- Golden Standard Classification;

- Mutation Mechanism;

- Integrated Referral System (SRT);

- Community Economic Development;

- Evaluation and Redefining.

Report Service Mechanism of GERTAK Post:

- Direct reports through Gertak Post

- Report through social media:

- Facebook;

- Twitter;

- Instagram;

- Whatsapp.

- Report through hotline:

- LAPOR Hotline;

- GERTAK Hotline.

- Report through the GERTAK Application.

Continuity and sustainability of Gertak Program innovation in Trenggalek Regency:

Institutional. To carry out its function as a poverty reduction program from the center, then some poverty programs that existed in Trenggalek Regency was directly managed by SKPD concerned with programs promoted by the local government. The programs managed by related SKPD consisted of: Unfit housing program that was located in SKPD of Housing, Settlement, and Cleanliness Agency (Dinas Perkimsih), Raskin (rice for the poor) program which was directly managed by Section of Public Welfare Secretary of Trenggalek Regency, and other programs that focused on the development of education, health, and others.

Budget Support. Trenggalek Regency Government issued aid funds to Gertak Post to help the poor through salary deductions from Civil Servants in Trenggalek Regency through BAZNAS (National Amil Zakat Board). BAZNAZ was expected to raise public awareness by initiating ASN to donate parts of civil servants' income to the poor. 
Human Resources. Gertak Post invited all components of the development drive (All OPD, DPRD (Regional House of People's Representatives), CSR, Business World, Academician, NGO, Profession Organization, Community, Sub-District Head, Village Head, and citizens) to take part on the success of GERTAK Program which became a measurement of acceleration of poverty prevention in Trenggalek Regency. Human Resources at Gertak Post will mobilize all parties to take part in the implementation of Gertak program in Trenggalek Regency.

SOP (Standard Operating Procedure). Handling poverty was the responsibility of all stakeholders and its handling was done across sectors, thus, giving birth to synergy in the implementation of poverty reduction programs. The success in poverty alleviation in Trenggalek Regency depended on program effectiveness and integration of poverty alleviation programs between central, provincial and regency governments. Therefore, accurate data, productive partnerships and participation of all components of society were required.

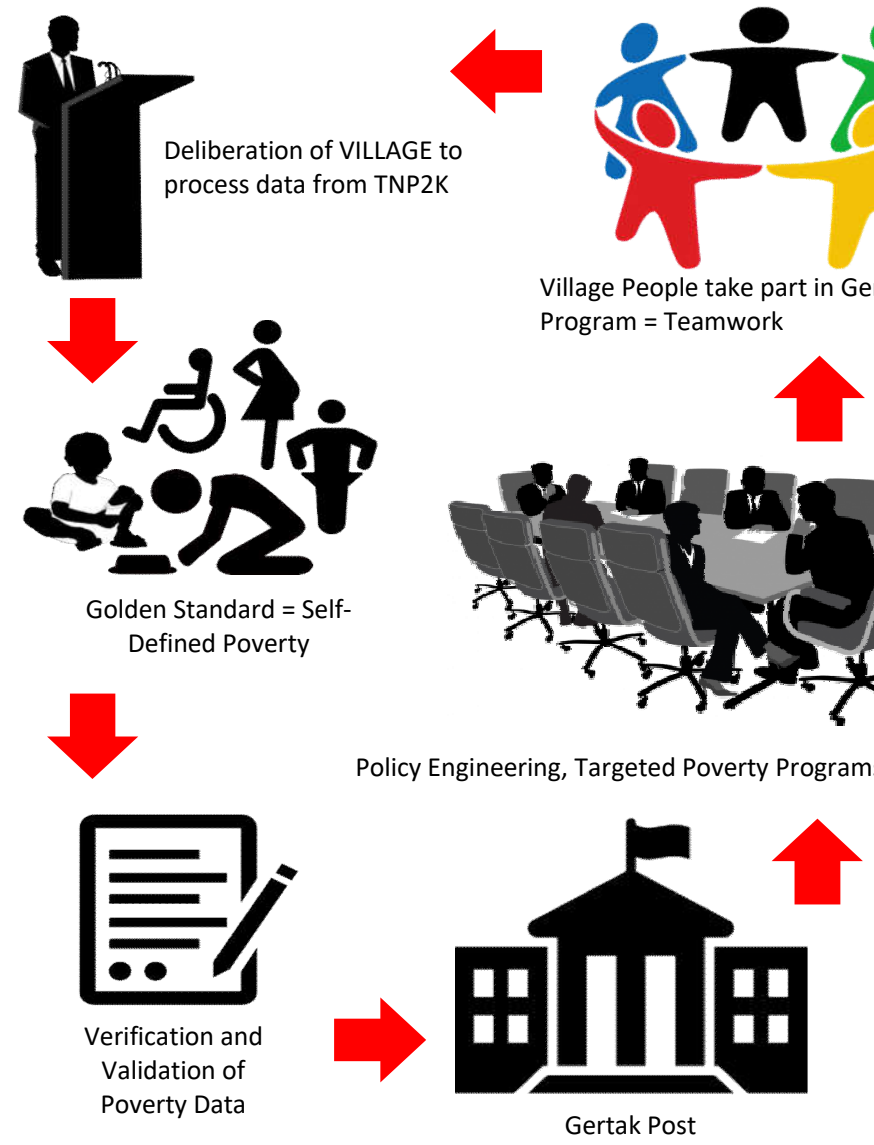

Figure 2 - Illustration of Gertak Program (Source: Gertak Journal, 2017)

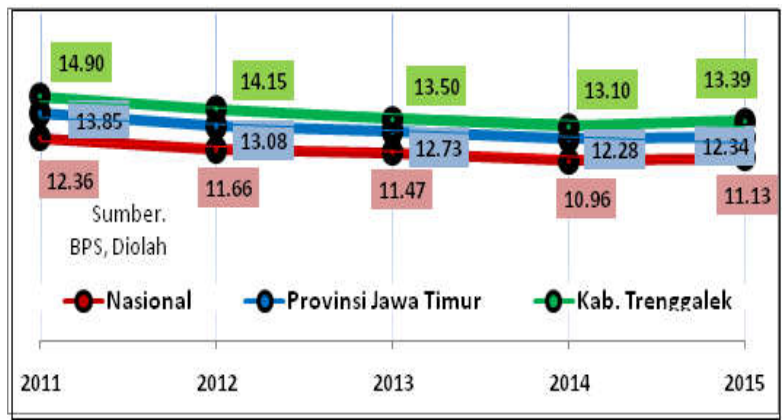

Figure 3 - Percentage of Poor People (P0) of Trenggalek Regency to East Java and National Provinces, 2011-2015 (Source: Gertak Journal, 2017) 
Poverty Reduction Innovation Relevance to Poverty Reduction through Gertak Program in Trenggalek Regency. The problem of poverty was not just the number and percentage of the poor. Another dimension to note was the depth and severity of poverty. In addition to being able to reduce the number of poor people, poverty policy also must be able to reduce the depth and severity of the poverty. The decline in poverty could not be separated from various poverty alleviation programs, both in central and regional level.

The poverty incidence rate in Trenggalek regency from 2011-2016 had decreased. In 2011 , the number of poor people was 101,200 people $(14.90 \%)$ and for 2014 the number of poor people decreased to 89,968 people $(13.10 \%)$. While in 2015 , the latest data from BPS (Central Bureau of Statistics) showed that the number of poor people increased to 92,170 people (13.39\%) and fell back in 2016 to 91,490 people $(13.24 \%)$. From this data, the poverty rate has decreased, but this figure was still above the average poverty rate of East Java Province $(11.75 \%)$ and National level $(10.80 \%)$. Thus, it was necessary to accelerate poverty eradication efforts in Trenggalek Regency (Gertak Journal, 2017 ).

\section{CONCLUSION}

This study aimed to reveal the facts obtained in the field and then would analyze the data based on relevant theory in order to provide accurate results. Based on the research that has been conducted, the researchers can convey the following conclusions:

Poverty reduction innovation in Trenggalek Regency implemented Gertak program in which the program would be able to eradicate poverty maximally and on target. The term GERTAK arised because Trenggalek Regency needed a breakthrough in overcoming poverty in Trenggalek. In addition, it was a matter of the live of the people, not just a matter of material. With a firm name, it was expected that there would be a spirit in eradicating poverty. The Gertak Program was well worth the effort to be innovative as it had multiple products and services that had already gained results in poverty reduction, namely:

- GERTAK invited poor people to look down on themselves, whether they were poor or whether there were many poorer relatives than themselves. The innovations offered were strengthening the role of TKPKD and developing an integrated poverty reduction management system through Self Defined Poverty System (SDPS).

- In Trenggalek Regency, the planning, budgeting, implementation, monitoring and evaluation process of the program was going well because the poverty reduction innovation program in Trenggalek was considered as a new program in its implementation. The position of TKPK of regencies/cities in Trenggalek Regency was a cross-sector and cross-agency forum as a forum for coordinating and synchronizing strategies, policies, programs and poverty reduction activities based in Trenggalek Regency and responsible to Trenggalek regent. The TKPK duty of Trenggalek Regency was coordinating and accelerating poverty reduction measures in Trenggalek regency.

- Budget support from the government of Trenggalek Regency had been compiled in as much detail as possible so that budget funds were not misplaced. This support was also taken from a few percent of salary of civil servants in Trenggalek Regency. Thus, for the issue of budget funds, it did not only come from APBD (Regional Expenditure Budget) from the government, but it also came from employees in Trenggalek Regency.

- Human resources in Gertak program involved all actors and components of poverty reduction drive in Trenggalek Regency. All OPD, DPRD, CSR, Business World, Academician, NGO, Profession Organization, Community, Sub-district Head, Village Head, and all community took part in the success of GERTAK Program which became a measurement of acceleration of poverty reduction in Trenggalek Regency. Human Resources at Gertak Post would mobilize all parties to participate and had excellent division of work in accordance with the ability of each field.

- The Gertak postal program already had SOP for the poor community's aid service that was in accordance with the guidelines that had been agreed upon. With SOP 
issued by Gertak, then there were some conditions that must be passed by the public complain. It was intended that the data collected by Gertak post was accurate and in accordance with procedures determined by the central government.

Analysis of relevance was a comparison between the policies made by the government of Trenggalek Regency, Provincial Government, and the Central Government. This policy was intended to see whether or not the policy undertaken by the Government of Trenggalek Regency was in line with the policy of the Provincial and Central Government. Trenggalek Regency showed almost the same movement (experienced a decrease) although its achievement was still above the provincial government and central government. It can be concluded that the relevance of poverty level between Trenggalek Regency, Provincial and National level showed that the policy in Trenggalek Regency was very relevant to the policies of the Provincial and National Governments, although the figure was still above the provincial and national figures. Thus, in this case, the government of Trenggalek Regency in its policy in reducing the poverty level had not succeeded in reducing the number of poor people.

\section{REFERENCES}

1. Creswell, J. W. (2012). Research design Pendekatan kualitatif, Kuantitatif dan Mixed. Yogyakarta: Pustaka Pelajar.

2. Moleong, L. J. (2010). Metode Penelitian Kualitatif. Bandung: PT. Remaja Rosadakarya.

3. Tontowi, A. (2010). Studi Implementasi Program Penanggulangan Kemiskinan Perkotaan (P2KP) di Desa Purbayan Kecamatan Baki Kabupaten Sukoharjo (Unpublished Master Thesis). Universitas Sebelas Maret, Surakarta.

4. Widodo, J. (2012). Analisis Kebijakan Publi: Konsep dan Aplikasi Analisis Proses Kebijakan Publik. Malang: Bayumedia Publishing. 